The Bangladesh Veterinarian (2012) 29(2) : $63-68$

\title{
Characterization of bacteria associated with omphalitis in chicks
}

\author{
S. Nasrin, M. A. Islam*, M. Khatun, L. Akhter and S. Sultana \\ Department of Microbiology and Hygiene, Faculty of Veterinary Science, Bangladesh \\ Agricultural University, Mymensingh-2202, Bangladesh
}

\begin{abstract}
This study was conducted to isolate and characterize the bacteria present in cases of omphalitis in chicks. Yolk swabs $(n=60)$ were aseptically collected from affected chicks and cultured for isolation and identification of bacteria. E. coli, Salmonella and Staphylococci were identified. Bacteria were tested for sensitivity to ten common antibiotics. E coli isolates were sensitive to chloramphenicol and resistant to nalidixic acid, ampicillin, amoxycillin, ciprofloxacin, tetracycline, gentamicin, sulphamethoxazole and erythromycin. Salmonella were sensitive to ciprofloxacin and resistant to tetracycline. Staphylococci were sensitive to ampicillin, amoxycillin, ciprofloxacin, gentamicin, sulphamethoxazole, erythromycin, chloramphenicol and kanamycin and resistant to nalidixic acid and tetracycline. The existence of multi-drug resistance emphasises the need to prevent omphalitis in chicks by hygiene. (Bangl. vet. 2012. Vol. 29, No. 2, 63 - 68)
\end{abstract}

\section{Introduction}

Omphalitis is one of the leading causes of mortality in newly hatched chicks (Rahman et al., 2007). It occurs due to unsanitary equipment in the hatchery. The affected chicks manifest depression, drooping of the head and huddling near to the heat source (Kahn et al., 2008). Several bacteria such as E coli., Salmonella spp., Proteus spp., Enterobacter spp., Pseudomonas spp., Klebsiella spp., Staphylococcus spp., Streptococcus spp., Clostridium spp., Bacillus cereus and Enterococcus have been isolated from the yolk sac of the infected birds (Cortes et al., 2004; Iqbal et al., 2006).

Early and accurate detection of bacteria is important to undertake appropriate control measure. Good management and sanitation as well as use of antibiotics help reduce mortality. The objectives of this study were to isolate the bacteria from clinical cases of omphalitis in newly hatched chicks in two hatcheries and to determine their sensitivity to ten common antibiotics.

\section{Materials and Methods}

\section{Collection of samples}

Yolk swabs $(n=60)$ were aseptically collected from newly hatched chicks at Bogra and Bangladesh Agricultural University (BAU) hatcheries manifesting signs of

\footnotetext{
*Corresponding author:- E-mail: arifmicro2003@yahoo.com
} 
omphalitis. At Bogra, 15 samples were collected from chicks 1-3 days old and 27 from chicks 4-7 days old. At BAU hatchery, ten samples were collected from chicks 1-3 days old and 8 from chicks 4-7 days old. Samples were transported to the laboratory at $4^{\circ} \mathrm{C}$.

\section{Isolation of bacteria}

Samples were enriched by overnight incubation in nutrient broth at $37^{\circ} \mathrm{C}$. Cultures were inoculated onto nutrient agar (NA), blood agar (BA), eosin methylene blue (EMB) agar, brilliant green agar (BGA), mannitol salt agar (MSA), salmonella-shigella (SS) agar and triple sugar iron (TSI) agar and incubated at $37^{\circ} \mathrm{C}$. Discrete bacterial colonies were sub-cultured until pure cultures were obtained (Cheesbrough, 1985).

\section{Characterization of bacteria}

Bacteria were characterised by recording morphology of colonies (size, margin, elevation and colour), Gram stain (Merchant and Packer, 1967), sugar fermentation, catalase, coagulase, M-R, V-P, indole, and triple sugar iron tests (Cheesbrough, 1985).

\section{Antibiotic sensitivity}

Antimicrobial sensitivity was tested using $0.5 \mathrm{McF}$ arland turbidity standard inoculum and freshly prepared, dried Mueller Hinton agar (Oxoid, UK) against 10 common antibiotics: nalidixic acid, ampicillin, amoxycillin, chloramphenicol, ciprofloxacin, tetracycline, kanamycin, gentamicin, sulphamethoxazole and erythromycin (Oxoid, UK). Five isolates of E. coli, Salmonella and Staphylococci were selected randomly for the test. Disc diffusion or Kirby-Bauer method (Bauer et al., 1966) was used. The results were expressed as resistant, intermediate or sensitive according to the guidelines of National Committee for Clinical Laboratory Standards (NCCLS, 2007).

\section{Results and Discussion}

\section{Isolation of bacteria}

Three genera of bacteria were isolated from yolk swab samples of chicks, E. coli, Salmonella and Staphylococci (Table 1). Bacterial genera recovered are in agreement with earlier studies (Sato et al., 1961; Zahdeh et al., 1984; Ijaz et al., 1994; Munir et al., 2004; Iqbal et al., 2006).

Table 1. Bacteria isolated from yolk swabs of chicks suffering from omphalitis in Bogra and BAU hatcheries

\begin{tabular}{l|c|c|c|c|c}
\hline \multirow{2}{*}{ Hatchery } & Chicken age & \multirow{2}{*}{ No of samples } & \multicolumn{3}{|c}{ No of bacterial isolates } \\
\cline { 4 - 6 } & & & E. coli & Salmonella & Staphylococci \\
\hline Bogra & $1-3$ days & 15 & 8 & 13 & 5 \\
& $4-7$ days & 27 & 15 & 18 & 7 \\
BAU & $1-3$ days & 10 & 4 & 3 & 1 \\
& $4-7$ days & 8 & 1 & 1 & 3 \\
\hline
\end{tabular}

BAU $=$ Bangladesh Agricultural University 


\section{Prevalence of bacteria}

The prevalence of bacteria associated with omphalitis in chicks is presented in Fig. 1.

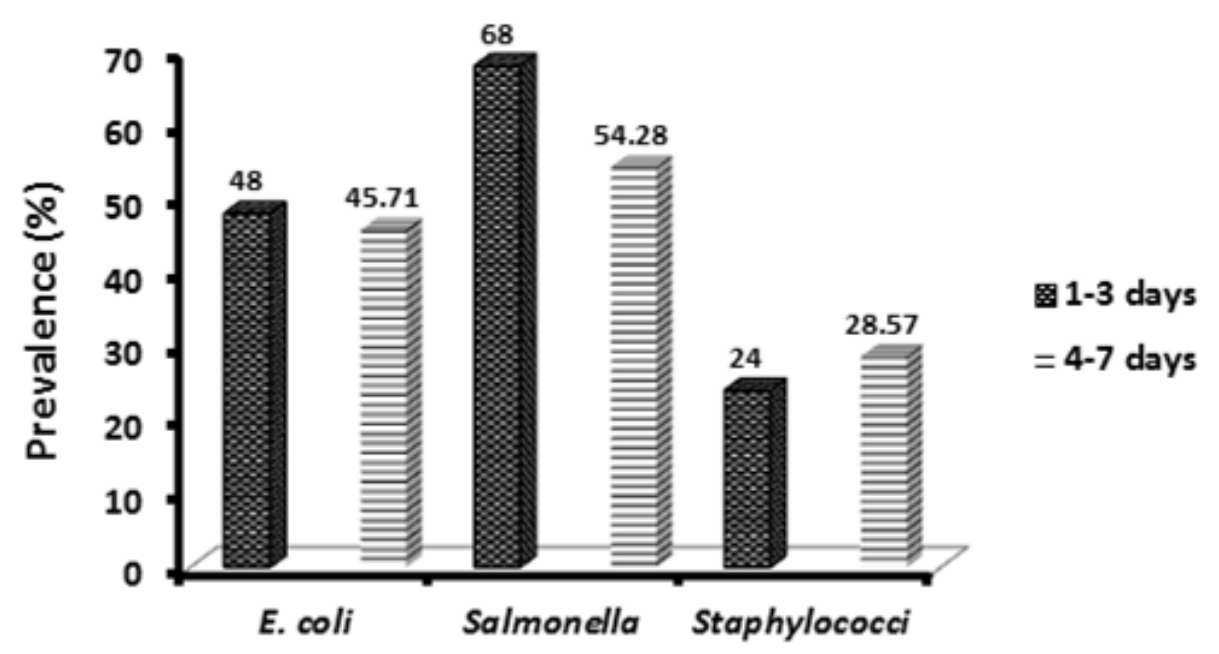

Fig. 1. Prevalence of E. coli, Salmonella and Staphylococci in 1-3 days and 4-7 days old chicks with clinical signs of omphalitis

In this study Salmonella showed the highest prevalence both in chicks aged 1-3 days and 4-7 days (68 and 54.3\%, respectively). These findings contradict the observation of Iqbal et al. (2006) who recorded a prevalence of $E$. coli $47.9 \%$ and only $0.5 \%$ prevalence of Salmonella. The prevalence of Staphylococci ranked third in this study (24\% in $1-3$ days old chicks and $28.6 \%$ in $4-7$ days old chicks), but a previous study recorded $0.5 \%$ prevalence of Staphylococci (Iqbal et al., 2006).

\section{Cultural, morphological and staining characteristics}

The cultural characteristics of E. coli, Salmonella and Staphylococci (Table 2) were similar to the findings of other authors (Choudhury et al., 1993; Nazir, 2004; Jakaria et al., 2012; Naurin et al., 2012).

\section{Biochemical characteristics}

E. coli fermented dextrose, lactose, sucrose and mannitol with the production of acid and gas. E. coli gave positive reaction to catalase and MR and indole tests and negative reaction in V-P test. Salmonella fermented dextrose, maltose and mannitol with acid and gas production. Salmonella were MR and catalase positive and negative to V-P and indole tests. Staphylococci fermented all five basic sugars with only acid production. Catalase, MR and V-P tests were positive but indole and coagulase tests were negative. These results are similar to those of Sato et al. (1961); Zahdeh et al. (1984) and OIE (2004). 
Table 2. Cultural characteristics of bacteria isolated from yolk swab samples of chicks suffering from omphalitis

\begin{tabular}{|c|c|c|c|c|c|c|c|}
\hline \multirow{2}{*}{$\begin{array}{l}\text { Bacterial } \\
\text { isolates }\end{array}$} & \multicolumn{7}{|c|}{ Cultural characteristics on } \\
\hline & NA & EMB agar & BA & BGA & MSA & SS agar & $\begin{array}{c}\text { TSI agar } \\
\text { slant }\end{array}$ \\
\hline E. coli & $\begin{array}{l}\text { Smooth, } \\
\text { circular, } \\
\text { white to } \\
\text { greyish } \\
\text { white } \\
\text { colony }\end{array}$ & $\begin{array}{l}\text { Large, } \\
\text { circular, } \\
\text { blue-black } \\
\text { colony with } \\
\text { green } \\
\text { metallic } \\
\text { sheen }\end{array}$ & $\begin{array}{l}\text { Colourless } \\
\text { colony } \\
\text { without } \\
\text { haemolysis }\end{array}$ & $\begin{array}{l}\text { Yellow } \\
\text { colour } \\
\text { colony }\end{array}$ & $\begin{array}{c}\text { No } \\
\text { growth }\end{array}$ & $\begin{array}{l}\text { Slight } \\
\text { growth } \\
\text { and pink } \\
\text { to rose- } \\
\text { red } \\
\text { colony }\end{array}$ & $\begin{array}{l}\text { Yellow slant } \\
\text { and butt } \\
\text { with gas but } \\
\text { no } \mathrm{H}_{2} \mathrm{~S} \\
\text { production }\end{array}$ \\
\hline Salmonella & $\begin{array}{l}\text { Circular, } \\
\text { smooth, } \\
\text { opaque and } \\
\text { translucent }\end{array}$ & $\begin{array}{l}\text { Pink colour, } \\
\text { circular and } \\
\text { smooth } \\
\text { colony }\end{array}$ & $\begin{array}{l}\text { Non- } \\
\text { haemolytic } \\
\text { colony }\end{array}$ & $\begin{array}{l}\text { Pale pink } \\
\text { colour } \\
\text { colony } \\
\text { against a } \\
\text { pinkish } \\
\text { background }\end{array}$ & $\begin{array}{c}\text { No } \\
\text { growth }\end{array}$ & $\begin{array}{l}\text { Black } \\
\text { centred, } \\
\text { smooth, } \\
\text { small } \\
\text { round } \\
\text { colony }\end{array}$ & $\begin{array}{l}\text { Butt remains } \\
\text { yellow and } \\
\text { slant } \\
\text { converted to } \\
\text { pink colour }\end{array}$ \\
\hline $\begin{array}{l}\text { Staphylo- } \\
\text { cocci }\end{array}$ & $\begin{array}{l}\text { Round, flat } \\
\text { colony of } \\
\text { sticky, } \\
\text { mucoid } \\
\text { consistency }\end{array}$ & No growth & $\begin{array}{l}\text { Round, } \\
\text { greyish and } \\
\text { mucoid } \\
\text { colony } \\
\text { without } \\
\text { haemolysis }\end{array}$ & No growth & $\begin{array}{l}\text { Small } \\
\text { grey- } \\
\text { white or } \\
\text { yellowish } \\
\text { colony }\end{array}$ & $\begin{array}{l}\text { No } \\
\text { growth }\end{array}$ & No growth \\
\hline
\end{tabular}

$\mathrm{NA}=$ nutrient agar; $\mathrm{EMB}=$ eosin methylene blue; $\mathrm{BA}=$ blood agar; $\mathrm{BGA}$ = brilliant green agar; MSA = mannitol salt agar; SS = salmonella-shigella; TSI = triple sugar iron. E. coli and Salmonella were Gram-negative, small rod-shaped single or paired. Staphylococci were Gram-positive, rod-shaped and arranged in clusters, in agreement with Freeman (1985) and Jones et al. (1997).

\section{Antibiotic sensitivity}

The results are presented in Table 3 .

Table 3. Antibiotic sensitivity of E. coli, Salmonella and Staphylococci

\begin{tabular}{l|c|c|c|c|c|c|c|c|c|c}
\hline \multicolumn{1}{c}{$\begin{array}{c}\text { Antimicrobial } \\
\text { agents }\end{array}$} & $\begin{array}{c}\text { Disc concentration } \\
(\mu \mathrm{g} / \mathrm{ml})\end{array}$ & \multicolumn{3}{c|}{$\begin{array}{c}\text { E. coli } \\
(\mathrm{n}=5)\end{array}$} & \multicolumn{3}{c|}{$\begin{array}{c}\text { Salmonella } \\
(\mathrm{n}=5)\end{array}$} & \multicolumn{3}{c}{$\begin{array}{c}\text { Staphylococci } \\
(\mathrm{n}=5)\end{array}$} \\
\cline { 3 - 11 } & & $\mathrm{R}$ & $\mathrm{I}$ & $\mathrm{S}$ & $\mathrm{R}$ & $\mathrm{I}$ & $\mathrm{S}$ & $\mathrm{R}$ & $\mathrm{I}$ & $\mathrm{S}$ \\
\hline Nalidixic Acid & 30 & 5 & 0 & 0 & 4 & 1 & 0 & 5 & 0 & 0 \\
Ampicillin & 10 & 5 & 0 & 0 & 2 & 0 & 3 & 0 & 1 & 4 \\
Amoxicillin & 10 & 5 & 0 & 0 & 3 & 0 & 2 & 0 & 1 & 4 \\
Chloramphenicol & 30 & 0 & 0 & 5 & 2 & 1 & 2 & 0 & 1 & 4 \\
Ciprofloxacin & 5 & 5 & 0 & 0 & 0 & 0 & 5 & 0 & 0 & 5 \\
Tetracycline & 30 & 5 & 0 & 0 & 5 & 0 & 0 & 5 & 0 & 0 \\
Kanamycin & 30 & 1 & 2 & 2 & 1 & 2 & 2 & 2 & 0 & 3 \\
Gentamicin & 10 & 5 & 0 & 0 & 0 & 3 & 2 & 0 & 1 & 4 \\
Sulphamethoxazole & 25 & 5 & 0 & 0 & 3 & 0 & 2 & 2 & 0 & 3 \\
Erythromycin & 15 & 5 & 0 & 0 & 5 & 0 & 0 & 1 & 2 & 2 \\
\hline
\end{tabular}

$\mathrm{R}=$ resistant; $\mathrm{I}=$ intermediate; $\mathrm{S}=$ sensitive 
All E. coli isolates were resistant to eight antibiotics: ciprofloxacin, gentamicin, amoxycillin, ampicillin, tetracycline, erythromycin, nalidixic acid and sulphamethoxazole. All Salmonella isolates were resistant to tetracycline and erythromycin. All Staphylococci were resistant to nalidixic acid and tetracycline. The results are identical with those by Klein et al. (1996); Khan et al. (2002); Lee et al. (2005); Nazir et al. (2005a, b); Akond et al. (2009).

\section{Conclusions}

The occurrence of multi-drug resistance in bacteria in chicks suffering from omphalitis is alarming as this resistance may gain access to man and animals, which might result in difficulties in treatment of bacterial infection. Further studies are required to formulate guidelines for the prevention and control of bacterial omphalitis in chicks in Bangladesh.

\section{References}

Akond MA, Alam S, Hassan SMR, Shirin M 2009: Antibiotic resistance of Escherichia coli isolated from poultry and poultry environment of Bangladesh. International Journal of Food Safety 11 19-23.

Bauer AW, Kirby WMM, Sherris JC, Truck M 1966: Antibiotic susceptibility testing by a standardized single disk method. American Journal of Clinical Pathology 45 493-496.

Cheesbrough M 1985: Microbiology. In: Medical laboratory manual for tropical countries. Vol. 2. English Language Book Society, London, pp. 225-392.

Choudhury BA, Chanda PD, Dutta RK, Saha L, Bhuin S, Saha L, Bhuin S 1993: Studies on yolk sac infection in poultry, antibiogram of isolates and correlation between in-vitro and in-vivo drug action. Indian Journal of Animal Health 32 21-23.

Cortes CR, Isaias GT, Cuello CL, Flores JMV, Anderson RC, Campos CE 2004: Bacterial isolation rate from fertile eggs, hatching eggs, and neonatal broilers with yolk sac infection. Revista Latinoamericana de Microbiologia 46 12-16.

Freeman BA 1985: In: Burrows text book of microbiology. 22nd edn. W. B. Saunders Company, Philadelphia, London, pp. 464-472.

Iqbal M, Shah IA, Ali A, Khan MA, Jan S 2006: Prevalence and in vitro antibiogram of bacteria associated with omphalitis in chicks. Pakistan Veterinary Journal 26 94-96.

Ijaz MM, Arshad M, Anwar M, Hussain, Iqbal M 1994: Studies on the prevalence of bacterial agents isolated from yolk of broiler chicks suffering from omphalitis. Journal of Animal Health and Production 14 51-54.

Jakaria ATM, Islam MA, Khatun MM 2012: Prevalence, characteristics and antibiogram profiles of Escherichia coli isolated from apparently healthy chickens in Mymensingh, Bangladesh. Microbes and Health 127-29. 
Jones TC, Hunt RD, King NW 1997: In: Veterinary Pathology. $6^{\text {th }}$ edn. Williams and Wilkins Co, Baltimore, USA, pp. 125-178.

Kahn CM, Line S, Aiello SE 2008: In: The Merck Veterinary Manual. 9th edn. Merck and Co, Inc, USA, pp. 2258-2259.

Klein LK, Robert JY, Cheryl AC, Sarah AS 1996: Minimum inhibitory concentrations of selected antimicrobial agents against bacteria isolated from 1-14-day-old broiler chicks. Journal of Veterinary Diagnostic Investigation 8 494-495.

Khan KA, Khan SA, Hamid S, Aslam A, Rabbani M 2002: A study on the pathogenesis of yolk retention in broiler chicks. Pakistan Veterinary Journal 22 80-83.

Lee YJ, Kim AR, Jung SC, Song SW, Kim JH 2005: Antibiotic resistance pattern of E. coli and Salmonella spp. isolated from chicken feces. Korean Journal of Veterinary Research 45 75-83.

Merchant IA, Packer RA 1967: In: Veterinary bacteriology and virology. $7^{\text {th }}$ edn. The Iowa University Press, Ames, Iowa, USA, pp. 286-306.

Munir Z, Hayat CS, Zeb A, Muneer MA, Haq I 2004: Surveillance of antibiogram and percent antibiotic resistance for infectious omphalitis in different poultry housing areas in Punjab. Pakistan Journal of Life and Social Science 2 182-184.

Naurin S, Islam MA, Khatun MM 2012: Prevalence of Salmonella in apparently healthy chickens in Mymensingh, Bangladesh. Microbes and Health 1 30-33.

Nazir KHMNH, Rahman MB, Nasiruddin KM 2004: Molecular base of diversified Escherichia coli isolates potentiating antibiotic resistant pattern and compromising epidemiology. MS Thesis, Department of Microbiology and Hygiene, Faculty of Veterinary Science, Bangladesh Agricultural University, Mymensingh.

Nazir KHMNH, Rahman MB, Khan MFR, Fakhruzzaman M, Rahman MS, Rahman M, 2005a: Relationship between antibiogram and plasmid profile analysis of Escherichia coli isolates of broiler and layer. Journal of Bangladesh Society for Agricultural Science and Technology 2 57-60.

Nazir KHMNH, Rahman MB, Nasiruddin KM, Akhtar F, Khan MFR, Islam MS 2005b: Antibiotic sensitivity of Escherichia coli isolated from water and its relation with plasmid profile analysis. Pakistan Journal of Biological Science 8 1610-1613.

National Committee for Clinical Laboratory Standards 2007: Performance standards for antimicrobial susceptibility testing; Seventeenth informational supplement. 27 M100S17, NCCLS, Wayne, PA.

OIE 2004: Manuals of standards for diagnostic test and vaccine. $4^{\text {th }}$ edn. France, pp. 446-456.

Rahman MM, Rahman AZ and Islam MS 2007: Bacterial diseases of poultry prevailing in Bangladesh. Journal of Poultry Science 1 1-6.

Sato G, Miura S, Miyamae T, Nakagawa M, Ito A 1961: Characters of Staphylococci isolated from dead chick embryos and from pathological conditions in chickens. Japanese Journal of Veterinary Research 9 1-13.

Zahdeh AH, Basioni AH, Awaad MH, 1984: Studies on the prevalence of bacterial agents isolated from yolk sacs of chicks showing omphalitis. Journal of Egyptian Veterinary Medical Association 36 359-371. 